\title{
Glucokinase-Associated Hyperinsulinism
}

National Cancer Institute

\section{Source}

National Cancer Institute. Glucokinase-Associated Hyperinsulinism. NCI Thesaurus. Code C131831.

Hyperinsulinism due to activating mutation(s) in the gene GCK, encoding glucokinase. 